\title{
- Is your work making you ill?
}

\section{Debasish Kar Mahapatra}

\section{IJCRR}

Section: Healthcare

Sci. Journal Impact

Factor: 6.1 (2018)

ICV: 90.90 (2018)
Chief Medical Officer (Retired), Medical Department, Western Coalfields Limited (Subsidiary Company of Coal India Limited), Nagpur 4400o1, Maharashtra, India.
Possibly this is the last thing that comes into your mind: How can my work make me ill? Illness can only be due to infection by some bacteria or virus because that is what we have been taught since our childhood. But didn't you get low back pain last week when the box you were lifting suddenly slipped and you had to take rest and medication for a few days? It was due to your work, wasn't it? So, your work made you sick. Well, it does: only that we aren't aware of it.

As we progress more towards globalization and a competitive environment, more do we feel the necessity of Occupational Health Services (OHS) in industries. So, what is it? In 1950, ILO / WHO defined Occupational Health as the promotion and maintenance of the highest degree of physical, mental, and social well-being of workers in all occupations by preventing departures from health, controlling risks, and the adaptation of work to people and people to their jobs.

Bernardino Ramazzini (1633-1714 AD), an Italian physician, is known as the "Father of Occupational Medicine" for his comprehensive book on Occupational Diseases, De Morbis Artificum Diatriba (Diseases of Workers) published in 1700 AD. It outlined the health hazards of chemicals, dust, metals, repetitive motions, odd postures, and disease-causing agents faced by workers in more than fifty occupations. This laid the foundation of this specialty and played a key role in its development. He added the question "What is your occupation?" To the case history of all patients before their medical examination. As a visionary, he emphasized on prevention as it was easier to foresee future harm and avoid it rather than get rid of it after falling prey to a disease or injury. In 1775 AD, Sir Percivall Pott described Chimney sweep's cancer and postulated that it was associated with occupational exposure to soot to which they had been exposed since their early childhood. Later on, it was proved that soot contained coal tar which had carcinogenic chemicals.

Occupational Health is now a vast subject that requires years of study and experience to master it. However, we may discuss its various aspects, in a nutshell, to appreciate what it is and what are the things it deals with at various types of the workplace:

\section{OCCUPATIONAL HAZARDS}

\author{
Physical: \\ - Heat --- causing burn, heat stroke, heat syncope; \\ - Cold --- causing frostbite, trench foot; \\ - Light --- causing occupational cataract, miner's \\ nystagmus; \\ - Noise --- causing Noise-Induced Hearing Loss \\ (NIHL); \\ - Vibration --- white fingers, injuries to joints; \\ - Radiation --- cancer
}

\section{Chemical:}

- Local action --- causing eczema, dermatitis;

- Inhalation of dust --- causing Pneumoconiosis (Silicosis, Byssnosis, Bagassosis, Asbestosis);

- Inhalation of gases --- Carbon monoxide, Ammonia;

- Toxic effects of Metals --- Lead, Mercury

\section{Biological:}

Leptospirosis, Brucellosis, fungal infections, etc.

\section{Mechanical:}

Accidents, improper design of workplace making it, Ergonomically incorrect, etc.

\section{Psycho-social:}

Frustration, lack of job satisfaction, poor human relation, tension, depression, etc.

Hence, Occupational Health focuses on the following objectives:

* Maintenance and promotion of workers' health and working capacity.

* Improvement of working environments to ensure that they are conducive to health and safety.

* The development of work culture in ways that support health and safety at work, promote positive social interactions, and improve productivity. 
Therefore, it has to be implemented by adopting the following measures:

* Medical: Pre-employment medical examination to assess the suitability of the worker for a particular job, to provide good medical facilities, Periodical medical examination to assess any departure from health. All medical records are to be maintained and analyzed to assess the clustering of disease amongst workers with an identical job profiles. Health Education and Counselling is an essential component towards prevention of health hazards and diseases.

* Engineering: The factory as also the actual workplace should be designed correctly along with proper ventilation, lighting, noise control, mechanization, and dust control. Environmental monitoring and record-keeping are essential to assess the health hazards associated with the work. Application of Ergonomics improves productivity and reduces musculoskeletal disorders.

* Legislation: Law protecting the health, safety, and welfare of workers go a long way in implementing OHS. Factories Act and Rules, Mines Act and Rules, Employees State Insurance Act, Workman's Compensation Act, etc. are examples.
These legislatures include Notifiable Diseases, Compensation, Occupational Diseases, Occupational Health Surveys, Employment in Hazardous Process, etc.

So, it can be well appreciated that OHS is a multi-disciplinary subject aimed at the welfare of society in general and workers in particular.

\section{REFERENCES}

1. Ferrett E. Introduction to Health and Safety at Work: for the NEBOSH National General Certificate in Occupational Health and Safety. Routledge; 2020.

2. Gokul K, Abirami SB. Occupational hazards among practicing dentists in Chennai-A Survey report. Int J Cur Res Rev. 2015;7(24):30-38.

3. Arezes PM, Baptista JS, Barroso MP, Carneiro P, Cordeiro P, Costa N, Melo RB, Miguel AS, Perestrelo G. Occupational and Environmental Safety and Health II. Springer International Publishing; 2020.

4. Debbarma D, Mitra S. Occupational health problems of the auto rickshaws service providers in Agartala city: a case study of Nagerjala motor stand. Int J Cur Res Rev. 2017;9(22):16-21.

5. Tamin J. Occupational Health Ethics: From Theory to Practice. Springer Nature; 2020. 